\title{
Voluntary disclosure and earnings management: evidence from the Brazilian capital market*
}

\author{
Silvia Consoni \\ Universidade Federal do Paraná, Departamento de Ciências Contábeis, Curitiba, PR, Brazil
}

\author{
Romualdo Douglas Colauto \\ Universidade Federal do Paraná, Departamento de Ciências Contábeis, Curitiba, PR, Brazil
}

Gerlando Augusto Sampaio Franco de Lima

Universidade de São Paulo, Faculdade de Economia, Administração e Contabilidade, Departamento de Contabilidade e Atuária, São Paulo, SP, Brazil

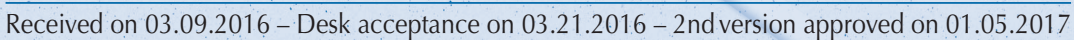

\begin{abstract}
This study examines the association between the voluntary disclosure of economic and financial information and earnings management. The outlined arguments on the subject are based on the assumption that consistent voluntary disclosure policies may reduce earnings management. The analysis is conducted on a random sample of 66 non-financial Brazilian listed companies in the 2005-2012 period. To measure voluntary disclosure, the index proposed by Consoni and Colauto (2016) is used. As a proxy for earnings management, discretionary accruals (DA) are estimated based on the model by Dechow, Sloan, and Sweeney (1995). The relationship between these measurements is analyzed using a model of simultaneous equations and by the random effects regression method with panel data. A significant negative relationship was expected $a$ priori; however, the main result of the study indicates that voluntary disclosure and earnings management are not simultaneously determined or associated. Although the results obtained contradict certain theoretical assumptions, there are alternative explanations for this finding. The empirical set of evidence in this research, in addition to those in previous studies, should be interpreted with caution because there is no consensus on the measures for voluntary disclosure and earnings management. Second, several companies in Brazil may not be interested in providing high-quality voluntary disclosure because most of their shareholders enjoy private benefits of control. This issue reduces the importance of the potential market demand for information, stratifies information asymmetry, and does not prevent earnings management.
\end{abstract}

Keywords: accounting information, voluntary disclosure, earnings management, emerging markets, discretionary accruals.

* Paper presented at the American Accounting Association Annual Meeting, Chicago, IL, United States of America, August 2015. 


\section{INTRODUCTION}

Although it is well known that corporate disclosure brings advantages such as greater stock market liquidity and a lower cost of capital (Botosan 1997, 2006; Lopes \& Alencar 2010; Welker 1995), managers are not always willing to increase the level of accounting disclosure. In addition to these benefits, there are most likely competing elements that may justify tighter managerial control over information, contributing to the importance of decisions about whether to disclose information.

Managers generally have access to more specific and accurate information about a company's business than do other market actors, but they may want to disclose or retain that information to serve their personal interests (Demsetz \& Lehn, 1985). According to Watts and Zimmerman (1986), in deciding which information to report, managers attempt to evaluate how alternative methods will affect their wealth.

According to Dye (1988), a manager enjoys an advantage over stockholders with regard to information because it is difficult for the latter to directly observe the company's performance and therefore identify its future business prospects. In this sense, Scott (2012) observes that this information asymmetry creates ideal conditions for selective and distorted information reporting and a temptation to moral hazard. Thus, greater information asymmetry allows managers to use their discretion for the specific purpose of managing accounting results.

Information asymmetry can be reduced through voluntary disclosure and tighter regulation (Scott, 2012). However, regulation in the context of agency conflict works only if the regulator can require the disclosure of information that market participants are unwilling to disclose voluntarily (Beyer, Cohen, Lys, \& Walther, 2010). According to Watts and Zimmerman (1986), the recognition, measurement, and disclosure of accounting data are not always guided by impartial decisions, but can be driven by economic incentives that maximize the expected utility of one of the interested parties. Managers overlook the fact that, in earnings management, accounting choices should be guided by the economic fundamentals of the company's business.

The guiding hypothesis of this study is that voluntary disclosure and earnings management are negatively related because this relationship is based on the relationship of each of these variables with information asymmetry. Healy and Palepu (2001), Lambert, Leuz, and Verrecchia (2007), and Verrecchia (1983) present voluntary disclosure as a factor that contributes to the reduction of information asymmetry. For Dye $(1985,1988)$ and Schipper (1989), among others, the information asymmetry between managers and investors is the necessary condition for earnings management. From this perspective, this study aims to investigate the relationship between voluntary disclosure of economic and financial information and earnings management in the Brazilian capital market.

Voluntary disclosure and earnings management are recurring themes in research on finance and accounting. However, there is little empirical evidence on the relationship between them that is specific to the Brazilian capital market. One example is the study by Murcia and Wuerges (2011), who explore this relationship from 2006 to 2008 using a sample of the 100 largest companies listed on the São Paulo Stock Exchange, Commodities and Futures (BM\&FBOVESPA) and report a partially negative association between voluntary disclosure and earnings management.

To deepen this discussion, the time period of 20052012 is explored. Part of this period is marked by adjustments resulting from the process of alignment with international accounting standards starting in 2008. Consoni and Colauto (2016) present evidence that this process can be understood as an exogenous factor that had a significant positive effect on voluntary disclosure in Brazil. Therefore, the index proposed by Consoni and Colauto (2016) is adopted as a metric for voluntary disclosure and, different from that of Murcia and Wuerges (2011), the proxy for earnings management that is used is the discretionary accruals (DA) estimated using the model by Dechow et al. (1995).

The analysis performed in this study reveals that voluntary disclosure and earnings management are neither co-determined nor associated. That is, the absence of a relationship between the variables investigated suggests that disclosure decisions are not an important determinant for the practice of earnings management in Brazil. For the U.S.A. (Jo \& Kim, 2007; Lobo \& Zhou, 2001) and British (Iatridis \& Kadorinis, 2009) markets, there is evidence of a negative association. Thus, it should be noted that different proxies for voluntary disclosure and earnings management make direct comparison difficult. Moreover, institutional differences between markets may influence both voluntary disclosure and earnings management.

Another crucial element is the understanding of voluntary disclosure as a response to information asymmetry. As observed by Francis, Nanda, and Olsson (2008), the assumption that voluntary disclosure is a determinant of the quality of earnings reported by 
companies ignores the fact that the voluntary disclosure may itself be based on poor-quality information. This point must be discussed and other methodologies must be used to better understand the behavior of voluntary disclosure and earnings management in the Brazilian context.

\section{LITERATURE REVIEW AND HYPOTHESIS DEVELOPMENT}

\subsection{Voluntary Disclosure of Information}

The demand for additional resources always increases when new investment opportunities appear and new investment opportunities are themselves likely to be associated with a widening gap in the information asymmetry between "insiders" and "outsiders" (Healy \& Palepu, 2001). Analytical models, such as those developed by Diamond and Verrecchia (1991), Glosten and Milgrom (1985), and Kim and Verrecchia (1994), show that information asymmetry decreases as the level of voluntary disclosure of information rises because and this can reduce the adverse selection component of the bid-ask spread (the mechanism for price protection when shares are bought and sold). As a result, the trade volume and stock market liquidity increase, possibly reducing the cost of capital.

According to Grossman (1981), Milgrom (1981), and Milgrom and Roberts (1986), without information disclosure, investors would be unable to distinguish between high-quality and low-quality stocks. A lack of information would lead investors to reexamine their beliefs about the company's value and, logically, offer an average price for the entire group of stocks evaluated. In this sense, managers have an incentive to disclose all of the data at their disposal to distinguish themselves from those with less favorable data. In turn, theory about voluntary corporate disclosure has concentrated on identifying the reasons that full disclosure does not in fact occur.

Some of the research conducted by Robert E. Verrecchia and Ronald A. Dye, or research to which these authors contributed, has aimed to formulate models to explain partial voluntary disclosure. Refuting Verrecchia's thesis (2001) that there is no unified theory of voluntary disclosure, Dye (2001) demonstrates that his arguments differ from those of Verrecchia in that they consider models of voluntary disclosure to be essentially endogenous, whereas Verrecchia (2001) attributes the same status to endogenous and exogenous models.

According to Dye (2001), the idea that voluntary disclosure is efficient and contributes to efficient resource allocation in the capital market is related to the credibility of the financial data disclosed. Although Verrecchia (2001) notes managers' propensity not to disclose data that are essentially true, Dye (2001) argues that Verrecchia omits what he considers the determining factor in the disclosure's credibility, earnings management.

In this sense, Core (2001) argues that unbiased disclosure is not a manager's ideal, given that it carries a high cost. This conclusion is based on Watts and Zimmerman's understanding (1986, p. 205) that not all accounting manipulation is eliminated and that only in capital markets with rational expectations will managers fail to benefit from manipulation. The notion that it is very expensive to eliminate manipulation entirely indicates that managers can introduce some disclosure bias at a low personal cost.

In Verrecchia's model (1983), the disclosure costs that hinder full disclosure do not vary based on the information that the manager possesses. In Verrecchia's view (1983), the discretionary disclosure policy of managers is influenced by the costs of disclosing data, but the managers' only motivation for divulging information is its effect on the company's value.

In contrast, Dye $(1985,1986)$ claims that disclosure costs vary with the nature of what is being disclosed. If investors are uncertain whether managers withhold private information, they cannot interpret a lack of information as a sign that the company in question is withholding bad news. In the eyes of investors, Dye argues, companies with bad news are therefore indistinguishable from companies that make no disclosures.

Uncertainty over how investors will interpret a disclosure causes managers to publish data based on how they believe investors will interpret it (Dye, 1985). To correctly interpret a manager's action, it is necessary to identify the manager's incentives to disclose good or bad news and the entire set of data that the manager could have disclosed, but chose not to. Discussion of this question has led Dye (2001) to state that voluntary disclosure is a special case of Game Theory because it is not always possible to conclude that managers disclose only information calculated to raise the company's stock price and hide information that will reduce it. The reason is that bad news may be released during labor negotiations or when options are being granted and good news may be released at the time these options are exercised. 
It is interesting to note that the benefits of corporate disclosure typically result in voluntary information disclosure, but not of all the information to which company management is privy. As noted by Dye (2001), the best information for the purpose of negotiating contracts is not necessarily the best information on which an investor should base a decision. Therefore, managers can strategically choose what to disclose and when to disclose it, provided that investors are uncertain as so what information the managers possess.

\subsection{Earnings Management}

Earnings management has been studied from many perspectives and methods. As a result, Mulford and Comiskey (2002) report that different characterizations have arisen, such as income smoothing, the reduction of current profits for the sake of future profits (big bath), creative accounting, and cosmetic financial statements (window-dressing), among others.

Healy and Wahlen (1999, p. 368) and Schipper (1989, p. 92) explain that earnings management can aim to modify both profit measures and economic and financial ratios, thereby modifying the form and content of accounting information. It is thus supposed that the practice of earnings management can interfere with the credibility of accounting data and its utility for decision-making by market actors. Thus, if earnings management is viewed as an opportunistic act, it must be viewed as reducing the quality of the published disclosure.

For Arthur Levitt (1998), former president of the Securities and Exchange Commission (SEC), earnings management stems from a decline in the quality of financial information disclosure, and measures requiring greater transparency and oversight of the financial statement disclosure process would be necessary to contain it. In Brazil, the Brazilian Securities Commission (CVM, by its Portuguese abbreviation) has also spoken on this subject. In Circular n. 480 (14 February 2007) (Comissão de Valores Mobiliários/Normas Contábeis e Auditoria/ Superintendência de Relações com Empresas, 2007), the CVM declared that it considers earnings management to be an arbitrary form of discretion intended to influence or manipulate accounting numbers, though it falls within the limits of the law.

Despite the reduction in data reliability that often accompanies the practice of earnings management, there are arguments that this practice can be useful if kept within certain limits. Fields, Lys, and Vincent (2001) and Schipper (1989) argue that earnings management may reveal information about the company's value. In this sense, Subramanyam (1996) and Burgstahler, Hail, and Leuz (2006) refer to the practice of earnings management as an opportunistic behavior, but not when management's discretion is used to better communicate the company's underlying economic and financial performance. Thus, if earnings management is used responsibly, then this practice can transmit private information to the market about expectations for future corporate earnings.

According to Dechow and Skinner (2000), the different interpretations of earnings management agree that the practice requires intentional management, but it is not clear whether that intention is merely opportunistic or designed to convey private information to investors. As a result, this aspect makes it difficult to achieve a comprehensive understanding of the motivations for this practice and leads to widely differing empirical results.

According to Schipper (1989, p. 95), it is the persistence of information asymmetry that makes earnings management possible. This condition arises from a contractually established form of communication that cannot be eliminated without changing the contract. Along this same line of reasoning, Dye (1988) argues that earnings management occurs when one or more hypotheses of the Revelation Principle are violated, given that monitoring mechanisms would force managers to reveal the truth about the information that they possess.

The Revelation Principle is present in the literature on the design of mechanisms. In this context, mechanisms refer to a set of incentives that causes the agent to act in a manner that maximizes utility for the principal (Myerson, 1979). According to Lambert (2001), the premises of the Revelation Principle are related to communication, the form of the contract, and the commitment taken on. Thus, the author explains that, according to the logic of mechanisms, when agents receive private information, they have the ability to transmit the information in its fullest dimension, i.e., when there are two signals, they will be transmitted as two separate messages rather than being aggregated into a single message.

Arya, Glover, and Sunder (1998) emphasize that individuals do not blindly follow the provisions established in contracts; as a result, problems in the mechanism's design arise from the difficulty of ensuring that the contracting parties fully disclose the information in their possession. In Dye's view (1988), when the mechanism is inefficient, managers hold an informational advantage over shareholders, which leads them to exercise their discretionary power to apply accounting standards 
in a manner that serves their own interest, given that shareholders cannot perfectly monitor the company's performance and observe the prospects of the business environment. Dye (2001) addresses this issue, noting that Verrecchia (2001) neglects what he considers to be the determining factor in the information's credibility, earnings management.

According to Watts and Zimmerman (1986), managers sometimes have the power to determine when an event will be shown in the accounts and which transactions will affect the results reported, such as the appropriation of a certain expense, revenue, and the disposal of assets. In this sense, Bushman, Engel, and Smith (2006) explain that profit may not be a good indicator for monitoring managers' efforts. One reason is that managers may choose accounting policies to maximize their own expected utility, managing the earnings opportunistically, and/or by reducing voluntary disclosure.

As suggested by LaFond and Watts (2008, p. 450), the private benefits of control give managers incentives to use private information to transfer wealth to themselves, "even in the absence of financial-reporting-based debt and compensation contracts". Furthermore, the institutional environment can interfere and provide various incentives for the practice of earnings management. The level of protection for the investor can guide corporate choices on issues such as governance, the dividend policy, the financial structure, and the shareholder control of companies.

The literature on earnings management suggests many explanations and/or motivations for this practice, with each of the explanations being applied to particular circumstances. Healy (1996, p. 108-109) suggests that the motivations for earnings management are ambiguous, making it difficult to establish appropriate methods for analyzing a certain behavior. In any given group of companies, some may act to reduce profit to reduce their tax burden or discourage potential competition, whereas others may inflate profits to maximize bonuses, meet analysts' projections, or obtain loans. Furthermore, all of these behaviors may be present in the same company over a given period.

Due to the variety of environments in which businesses operate, it is difficult for a single explanation to cover all environments. In summary, it appears that earnings management occurs because there is no precise measure of net income and because the generally accepted accounting principles (GAAP) cannot completely constrain the subjectivity inherent in accounting policy choices and in certain practices. Many decisions about accounting choices are complex and defy a simple answer about which best informs the investor.

Therefore, the issue of information asymmetry presents itself as a link between voluntary disclosure and earnings management and supports the research hypothesis. To inform stakeholders, managers can voluntarily disclose qualitative and quantitative information that goes beyond that which is required by law.

Through voluntary disclosure, managers can show current and prospective earnings to those interested in the financial position of the company or they can clarify and explain the criteria adopted for the company's formulation of its accounting policies and estimates (Lundholm, 2003). According to Lambert et al. (2007), this effort aims to reduce information asymmetry and thereby increase investors' ability to make decisions and accurately monitor their investments.

Dye $(1985,1988)$ and Schipper (1989) consider the information asymmetry between managers and shareholders to be a necessary condition for earnings management. Schipper (1989) states that high levels of information asymmetry between managers and shareholders indicate a lack of sufficient resources, incentives, or access to relevant information for managers' actions to be monitored.

Trueman and Titman (1988) base their work on the assumption that voluntary disclosure increases transparency and that earnings management would therefore be more easily detected by shareholders of companies with a more consistent voluntary disclosure policy. Under these circumstances, managers would be less likely to practice earnings management because its purpose and effectiveness depend on the level of information asymmetry between managers and other market participants. Thus, managers would limit the level of voluntary disclosure if they wanted to maintain the flexibility to engage in earnings management.

Richardson (2000) explores these arguments, suggesting that the level of earnings management increases as the level of information asymmetry increases; testing this relationship, he finds a positive correlation. Richardson believes that this evidence indicates that, when information asymmetry is high, parties interested in the accounting data cannot obtain access to the information necessary to prevent accounting manipulation. Therefore, as information asymmetry increases, managers can use their discretion to manage reported earnings. Along the same lines, Iatridis and Kadorinis (2009), Jo and Kim (2007), and Lobo and Zhou (2001) find voluntary 
disclosure to be inversely correlated with earnings management. Based on the theoretical predictions and empirical results discussed, the research hypothesis is as follows:
$\mathrm{H}_{1}$ : as the index of voluntary disclosure of economic and financial information increases, the level of earnings management decreases.

\section{METHODOLOGY}

\subsection{Measurement of Voluntary Disclosure}

To explore what underlies the objective of this study and the specifics of the context being analyzed, as Botosan (2004) refers to it, this study employs the metric proposed by Consoni and Colauto (2016) for measuring the content of voluntary disclosures (Table 1). These researchers conceive the metric grounded in Brazilian studies and define its content based on the elements that continue to be voluntary over the time period of the study. This aspect of the methodology is relevant in the context of this analysis because, starting in 2008, Brazil began the process of aligning with the international accounting standards. In addition, in 2009, the CVM began to require companies to file a Reference Form, which replaced the Annual Information Form (IAN, by its Portuguese abbreviation), and contributed to changing the nature of disclosure and increasing the volume and detail of the disclosed information.

Table 1 Voluntary disclosure index

\begin{tabular}{|c|c|}
\hline \multicolumn{2}{|r|}{ Market view } \\
\hline 1 & Competitive analysis \\
\hline 2 & Market share \\
\hline 3 & Assessment of major economic trends market \\
\hline 4 & Government influence on the company activities \\
\hline \multicolumn{2}{|r|}{ Corporate strategy } \\
\hline 5 & Plans and corporate objectives \\
\hline 6 & Alignment of company activities with the stated objectives \\
\hline 7 & Prospect of new investments \\
\hline 8 & Sales forecasts \\
\hline 9 & Earnings forecasts \\
\hline 10 & Cash flow forecasts \\
\hline \multicolumn{2}{|r|}{ Economic and financial performance } \\
\hline 11 & Variation in the inventories of goods for sale, inputs or finished products \\
\hline 12 & Variation in the level of receivables \\
\hline 13 & Variation in the volume of sales \\
\hline 14 & Variation in the level of administrative and commercial expenses \\
\hline 15 & Variation in the level of operational earnings \\
\hline 16 & Variation in the cost of goods sold, the products manufactured or services provided \\
\hline 17 & Financial effect from the raising of short and long-term third-party resources \\
\hline 18 & Financial effect from the application of own resources \\
\hline 19 & Performance of common and preferred shares \\
\hline 20 & Global indicators (EVA, EBITDA, MVA) \\
\hline 21 & Cost of equity \\
\hline \multicolumn{2}{|r|}{ Operational aspects } \\
\hline 22 & Current production compared to the installed capacity \\
\hline 23 & Operational efficiency measures \\
\hline 24 & Dependence of technology, suppliers, customers and labor \\
\hline 25 & Investments and divestments \\
\hline 26 & Resources invested in human capital management \\
\hline 27 & Resources invested in education projects, culture and social development \\
\hline
\end{tabular}

Source: Adapted from Consoni and Colauto (2016). 
This metric favors economic-financial information, although voluntary disclosure is not restricted to this content. It is understood that this limitation guides the analysis and is primarily due to the difficulty of evaluating the disclosure of socio-environmental information in heterogeneous samples. Occasionally, this type of information is linked to details of corporate activities in certain segments of the market and may even be disclosed to meet regulatory requirements for that sector of the market.

The procedures for data collection are the same as those adopted by Consoni and Colauto (2016), aligning the scope of each item of the metric with the content of statements in the Management Report and, where applicable, in some sections of the IAN and Reference Form. To take advantage of the fact that some companies disclose more detailed information, these researchers define coding criteria that consider how detailed the information is, in both qualitative and quantitative terms. Therefore, when no information is available for a certain item, a score of 0 is assigned; when only qualitative information is available, presented in descriptive terms, 1 point is assigned; and when both qualitative and quantitative information is available (in monetary or non-monetary terms), 2 points are assigned.

The absolute individual score ranges from 0 to 54 points (27 items measured, each worth a maximum of 2 points). The index, which is a proxy for voluntary disclosure, is obtained by dividing of the absolute score of each company for each year by the maximum possible score. The closer the ratio is to 1 , the better the company's voluntary disclosure is.

Along the same line presented by Francis et al. (2008), it is understood that a voluntary disclosure policy comprises a stable set of disclosure practices. Although voluntary disclosure also occurs in conference calls, websites, and newspapers, the documents cited are consulted because they are subject to a fairly uniform presentation framework, making it possible to compare companies and monitor the regularity of their disclosures.

\subsection{Measuring Earnings Management}

According to Dechow and Dichev (2002, p. 3940 ), accruals are temporary adjustments that delay or anticipate the recognition of cash flows. Because not all financial decisions are directed at earnings management, researchers have separated total accruals into discretionary (opportunistic behavior) and non-discretionary (related to the level of business activity) accruals. The literature offers a variety of models for estimating DA, many of which are attempts to improve on previous models. For this study, we use the model by Dechow et al. (1995), known as the Modified Jones model. This model uses aggregate accruals to try to estimate a "normal" level of accruals and deviations from this level are considered evidence of earnings management. The advantages and disadvantages of this model have been discussed by Dechow, Ge, and Schrand (2010), DeFond (2010), Fields et al. (2001), Guay, Kothari, and Watts (1996), Lo (2008), Thomas and Zhang (2000), and Young (1999), among others, but no alternative approach offers a superior solution. According to Subramanyam (1996), the DA estimated by this model are priced by the market.

To estimate the DA, it is first necessary to calculate the total accruals obtained using the balance sheet approach. The total accruals of company $i$ at time $t$ is defined as follows:

$$
T A_{i, t}=\left(\Delta C A_{i, t}-\Delta \operatorname{Cash}_{i, t}\right)-\left(\Delta C L_{i, t}-\Delta C F L_{i, t}\right)-\operatorname{Depr}_{i, t} / A_{i, t-1}
$$


where $T A_{i, t}$ is the total accruals of company $i$ at time $t$, $\Delta C A_{i, t}$ is the variation in the current assets of company $i$ at the end of time $t-1$ to the end of time $t, \Delta$ Cash $_{i, t}$ is the variation in the available cash of company $i$ from the end of time $t-1$ to the end of time $t, \Delta C L_{i, t}$ is the variation in the current liabilities of company $i$ from the end of time $t-1$ to the end of time $t, \triangle C L F_{i, t}$ is the variation in the short-term loans and financing of company $i$ from the end of time $t-1$ to the end of time $t$, Depr $_{i, t}$ is the amount of depreciation, amortization, and depletion of company $i$ during time $t$, and $A_{i, t-1}$ is the total assets of the company at the end of time $t-1$.

DA are estimated using pooled ordinary least squares (OLS) with the following equation:

$$
T A_{i, t}=\alpha_{1}\left(\frac{1}{A_{i, t-1}}\right)+\alpha_{2}\left(\Delta R E V_{i, t}-\Delta R E C_{i, t}\right)+\alpha_{3}\left(P P E_{i, t}\right)+\varepsilon_{i, t}
$$

where $\triangle R E V_{i, t}$ is the variation in the net revenue of company $i$ from time $t-1$ to time $t$, weighted by the total assets at the end of time $t-1, \triangle R E C_{i, t}$ is the variation in the accounts receivable (net) of company $i$ from time $t-1$ to time $t$, weighted by the total assets at the end of time $t-1$, $P P E_{i, t}$ is the balance of the fixed asset accounts (gross) of company $i$ from time $t-1$ to time $t$, weighted by the total assets at the end of time $t-1$, and $\varepsilon_{i, t}$ is the error term of company $i$ for time $t$.
All model variables are deflated by the total assets of the previous time period $\left(A_{i, t-1}\right)$ to minimize the effect of company size and the problem of heteroscedasticity. Regarding the parameters of the modified Jones model, the fixed assets and the difference in variation between net revenue and accounts receivable are the main drivers of the process of recognizing accruals. Using the estimated coefficients $\alpha_{1}$ and $\alpha_{2}$ of each company-year (equation 2), the non-DA $\left(N D A_{i, t}\right)$ are calculated as follows:

$$
N D A_{i, t}=\hat{a}_{1}\left(\frac{1}{A_{i, t-1}}\right)+\hat{a}_{2}\left(\Delta R E V_{i, t}-\Delta R E C_{i, t}\right)+\hat{a}_{3}\left(P P E_{i, t}\right)
$$

The absolute DA $\left(D A_{i, t}\right)$ represent the difference between total accruals $\left(T A_{i, t}\right)$ and non-DA $\left(N D A_{i, t}\right)$ as follows:

$$
D A_{i, t}=T A_{i, t}-N D A_{i, t}
$$

In this sense, DA are the residuals of the regression. The farther the residual is from 0 (whether positive or negative), the greater the level of earnings management is. Table 2 shows the estimates of the parameters obtained by the Modified Jones model. 
Table 2 Coefficients estimated by the Modified Jones model (2005-2012)

\begin{tabular}{|c|c|c|c|c|c|c|}
\hline & Expected sign & Coefficient & Standard Error & $\mathbf{t}$ & p-value & VIF \\
\hline Constant & & 0.0595 & 0.0261 & 2.2788 & $0.0231^{* *}$ & - \\
\hline$\alpha_{1}$ & & 2330.4 & 1109.42 & 2.1006 & $0.0362 * *$ & 1.001 \\
\hline$\alpha_{2}$ & $+/-$ & -0.2219 & 0.0454 & -4.8874 & $0.0000^{* * *}$ & 1.002 \\
\hline$\alpha_{3}$ & - & -0.0872 & 0.0452 & -1.9283 & $0.0544^{*}$ & 1.003 \\
\hline $\mathrm{R}^{2}$ & & & & & & 0.0565 \\
\hline $\mathrm{R}^{2}$ - adjusted & & & & & & 0.0511 \\
\hline$F(3.524)$ & & & & & & $10.46^{* * *}$ \\
\hline Durbin-Watsc & istic & & & & & 2.000 \\
\hline White's test & & & & & & $39.11^{* * *}$ \\
\hline Normality of & & & & & & $125.55^{* * *}$ \\
\hline Observations & & & & & & 528 \\
\hline
\end{tabular}

Note: the dependent variable is total accruals (TA).

coefficient $\alpha_{1}=1 / A_{i, t-1}$; coefficient $\alpha_{2}=$ variation in the net revenue of company $i$ from time $t-1$ to time $t$, weighted by the total assets at the end of time $t-1$, minus the variation in accounts receivable of company $i$ from time $t$ - 1 to time $t$, weighted by the total assets at the end of time $t-1$; coefficient $\alpha_{3}=$ balances of fixed assets accounts (gross) of company $i$ at the end of time $t$, weighted by total assets at end of time $t-1$; VIF = variance inflation factor.

*, **,***: significant at the 10,5, and 1 levels, respectively.

Source: Prepared by the authors.

The variance inflation factor shows that the model does not have multicollinearity problems in the specification. The Durbin-Watson statistic shows that there is no serial autocorrelation. In turn, the model's residuals do not follow a normal distribution. Nevertheless, according to Wooldridge (2002, p. 167), the OLS estimators satisfy asymptotic normality; that is, they have an approximately normal distribution in sufficiently large sample sizes. White's test detects heteroscedasticity, which makes the OLS estimators inefficient.

The $\alpha_{2}$ coefficient is negative and related to the difference in variation between net revenue and accounts receivable. Theoretically, the sign expected for this coefficient is difficult to predict because it is related to the increase in accruals, both for increasing and decreasing reported earnings. The $\alpha_{3}$ coefficient represents fixed assets, which is responsible for expenses associated with depreciation, amortization, and depletion and, as expected, is positively correlated with these expenses.

\subsection{Statistical Model}

The research strategy is designed based on a simultaneous equations model. From the theoretical arguments outlined in the literature, it is assumed that corporate disclosure policy and the management of accounting data result from endogenous decisions. Therefore, the following two structural equations are defined to compose the system of simultaneous equations:

$$
\begin{gathered}
D A_{i, t}=\alpha_{0}+\alpha_{1} V D I_{i, t}+\alpha_{2} R O A_{i, t-1}+\alpha_{3} L E V_{i, t}+\alpha_{4} I F R S_{i, t}+\alpha_{5} S I Z E_{i, t}+\varepsilon_{i, t} \\
V D I_{i, t}=\alpha_{0}+\alpha_{1} D A_{i, t}+\alpha_{2} C O N_{i, t}+\alpha_{3} L I Q_{i, t}+\alpha_{4} I F R S_{i, t}+\alpha_{5} S I Z E_{i, t}+\varepsilon_{i, t}
\end{gathered}
$$

where $D A_{i, t}$ is the discretionary accruals of company $i$ at time $t, V D I_{i, t}$ is the index of voluntary disclosure of company $i$ at time $t, R O A_{i, t-1}$ is the ln of the profitability of corporate assets for company $i$ from the end of time $t-1$ to the end of time $t, L E V_{i, t}$ is the ln of the book leverage of company $i$ at the end of time $t, L I Q_{i, t}$ is a dummy for the liquidity of the shares of company $i$ at the end of time $t, \operatorname{IFRS}_{i, t}$ is a dummy for the period of alignment with international financial reporting standards of company $i$ at time $t$, taking the value of 1 for the 2009-2012 period and 0 otherwise, $S I Z E_{i, t}$ is the size of the company, as measured by the ln of the total assets of company $i$ at time $t, C O N_{i, t}$ is the control rights, as measured by the percentage of common shares held by the main controlling shareholder or the sum of the percentages of common shares held by those who participate in the shareholders' agreement for company $i$ at time $t$, and $\varepsilon_{i, t}$ is the error term for company $i$ at time $t$. 
The two-stage least squares (2SLS) method is used to estimate the system of simultaneous equations. The OLS method produces inconsistent estimators for models with endogenous explanatory variables. In turn, if no endogenous explanatory variables exist, or in the case of weak instruments, then the 2SLS method produces inefficient estimators, i.e., they lack the minimum variance.

\subsection{Sample}

This study employs the same sample of companies that is used in Consoni and Colauto (2016). The sampling procedure favors the random selection of companies that have maintained an active registration in the BM\&FBOVESPA during the 2005-2012 period, excluding financial companies. By calculating the minimum size for finite populations, with a significance level of $5 \%$ and a $10 \%$ margin of error, Consoni and Colauto obtain a sample of 66 companies, representing 32\% of the population considered.

These criteria lead to the formation of a balanced panel containing 568 observation-years. Companies in the electric power and the steel and metallurgy sectors predominate in the sample, totaling $30 \%$. Over $55 \%$ of the sample companies belong to the traditional market and, on average, the concentration of control rights is
$73 \%$, as measured by the percentage of common shares held by the controlling shareholder or, in some specific cases, the sum of common shares held by participants in the shareholders' agreement.

In considering whether the sample is appropriate for the aims of this study and, consequently, the analysis of its results, the following factors are taken into consideration: (i) The sample has survival bias; that is, companies that closed or went public after 2005 are not included in the sample. Including only companies with active registrations makes it possible to indirectly control for the potential effects of economic and regulatory changes on the main variables of the study, particularly on voluntary disclosure. In addition, this study seeks to monitor the consistency of companies' voluntary disclosure policies. However, the survival bias makes it more difficult to generalize the results; (ii) To avoid impairing the measurement of some variables, such as the proxy for earnings management, companies in the finance and insurance sector are excluded from the sample because they have their own rules, chart of accounts, and specific property that are not comparable to other sectors; (iii) A sample of 66 company-years makes it possible to construct a disclosure index, given that, according to Core (2001), disclosure indices require intensive manual labor and are viable only for small samples.

\section{RESULTS}

\subsection{Regression Analysis Using 2SLS}

The results obtained by the 2SLS and the diagnostic statistics for the estimates are presented in Table 3.

Table 3 Summary of results for the two-stage least squares regression

\begin{tabular}{|c|c|c|}
\hline Independent variables & Equation 5 & Equation 6 \\
\hline VDI instrumented & $-0.7102^{* * *}(0.2470)$ & - \\
\hline DA instrumented & & $-0.0224 *(0.0120)$ \\
\hline \multicolumn{3}{|c|}{ Auxiliary regression } \\
\hline Instruments & Endogenous VDI & Endogenous DA \\
\hline $\mathrm{VDI}_{\mathrm{t}-1}$ & $\begin{array}{c}0.8495^{* * *} \\
(0.0473)\end{array}$ & \\
\hline $\mathrm{VDI}_{\mathrm{t}-2}$ & $\begin{array}{c}0.0464 \\
(0.0464)\end{array}$ & \\
\hline $\mathrm{DA}_{\mathrm{t}-1}$ & & $\begin{array}{c}0.4313^{* * *} \\
(0.0428)\end{array}$ \\
\hline $\mathrm{DA}_{\mathrm{t}-2}$ & & $\begin{array}{c}0.5273^{* * *} \\
(0.0425)\end{array}$ \\
\hline Shea partial $R^{2}$ & 0.7909 & 0.9079 \\
\hline Sargan & 0.473 & 0.160 \\
\hline
\end{tabular}


Table 3 Cont

\begin{tabular}{lcc}
\hline p-value & 0.4916 & 0.6893 \\
\hline Hansen J & 9.86 & 6.60 \\
\hline -value & 0.079 & 0.252 \\
\hline Wu-Hausman & 0.165 & 0.846 \\
\hline p-value & 0.685 & 0.358 \\
\hline Observations & 396 & 396 \\
\hline
\end{tabular}

Equation 5: $D A_{i, t}=\alpha_{0}+\alpha_{1} V D I_{i, t}+\alpha_{2} R O A_{i, t-1}+\alpha_{3} L E V_{i, t}+\alpha_{4} I F R S_{i, t}+\alpha_{5} S I Z E_{i, t}+\varepsilon_{i, t}$

Equation 6: $V D I_{i, t}=\alpha_{0}+\alpha_{1} D A_{i, t}+\alpha_{2} C C O N_{i, t}+\alpha_{3} L I Q_{i, t}+\alpha_{4} I F R S_{i, t}+\alpha_{5} S I Z E_{i, t}+\varepsilon_{i, t}$

Note: standard error in parentheses. Regressions with exogenous variables not reported in table.

$D A=$ discretionary accruals; $V D I=$ voluntary disclosure index.

*,**,***: significant at the $10 \%, 5 \%$, and $1 \%$ levels, respectively.

Source: Prepared by the authors.

The Shea $\mathrm{R}^{2}$ statistic from the first-stage regression indicates that the instruments are relevant in explaining the endogenous regressors. To ensure over identification, the lagged endogenous variables are used as instruments. The Sargan test of over identifying restrictions is used to assess the fit of the instruments. This test evaluates the statistical plausibility of the assumption that the instruments are exogenous. The result shows that the instruments are statistically relevant. To perform analyses with appropriate estimators, it is necessary to test simultaneity between DA and VDI, adopting the Wu-Hausman specification test. The test indicates that the residuals are not significant, as reported in Table 3; thus, it is impossible to reject the null hypothesis of exogeneity. In other words, DA and VDI show no simultaneous relationship in this model.

The estimation of models with endogenous explanatory variables by the OLS method produces inconsistent estimators. However, the 2SLS method for estimating models produces inefficient estimators that lack the minimum variance when no endogenous explanatory variables exist or in the case of weak instruments. Because there are no indications of simultaneity, it is more efficient to use the OLS method.

\subsection{Regression Analysis of Panel Data}

Panel data, specifically the fixed effects model, may be used to identify the sequential interrelationship between the DA and VDI variables. However, if only one of the relationships is significant, a unidirectional relationship will be observed between these variables. Therefore, the equations are estimated individually. First, the functional relationship between the dependent and independent variables is tested to observe the behavior of the VDI variable and of the control variables in relation to the DA and vice versa.

The Hausman test for the null hypothesis of the consistency of random effects estimators indicates that the fixed effects estimators are less efficient; thus, the random effects model is deemed more suitable. The results of the panel diagnostic tests and other results are shown in Table 4. 
Table 4 Random effects model with panel data

\begin{tabular}{|c|c|c|c|c|c|c|}
\hline \multirow{2}{*}{$\begin{array}{l}\text { Independent variables } \\
\text { VDI }\end{array}$} & \multirow{2}{*}{$\frac{\text { Expected sign }}{+}$} & \multicolumn{2}{|c|}{ Equation 5} & \multirow[t]{2}{*}{ Expected sign } & \multicolumn{2}{|c|}{ Equation 6} \\
\hline & & 0.0253 & $(0.0956)$ & & & \\
\hline DA & & & & - & -0.0127 & $(0.0165)$ \\
\hline LEV & + & $0.1272^{* * *}$ & $(0.0376)$ & & & \\
\hline $\mathrm{ROA}_{\mathrm{t}-1}$ & + & 0.3318 & $(0.2115)$ & & & \\
\hline CON & & & & - & 0.0001 & $(0.0003)$ \\
\hline LIQ & & & & + & $0.0355^{* *}$ & $(0.0138)$ \\
\hline SIZE & - & 0.0391 & $(0.0256)$ & + & $0.0544^{* * *}$ & $(0.0074)$ \\
\hline IFRS & $+/-$ & -0.0012 & $(0.0182)$ & $+/-$ & $0.0566^{* * *}$ & $(0.0074)$ \\
\hline Coefficient & $+/-$ & $-0.7832^{*}$ & $(0.4068)$ & $+/-$ & $-0.4103^{* * *}$ & $(0.1066)$ \\
\hline $\mathrm{R}^{2}$-within & \multicolumn{4}{|c|}{0.04} & \multicolumn{2}{|c|}{0.25} \\
\hline $\mathrm{R}^{2}$-between & \multicolumn{4}{|c|}{0.03} & \multicolumn{2}{|c|}{0.41} \\
\hline $\mathrm{R}^{2}$-overall & \multicolumn{4}{|c|}{0.03} & \multicolumn{2}{|c|}{0.38} \\
\hline Observations & \multicolumn{3}{|c|}{528} & & \multicolumn{2}{|c|}{528} \\
\hline Panel diagnosis & & Coefficient & p-value & & Coefficient & p-value \\
\hline Chow test & & 125.3300 & 0.0000 & & 20.8789 & 0.0000 \\
\hline Breusch-Pagan test & & 1611.6700 & 0.0000 & & 912.7820 & 0.0000 \\
\hline Wu-Hausman test & & 1.9844 & 0.8513 & & 3.7747 & 0.5823 \\
\hline
\end{tabular}

Equation 5: $D A_{i, t}=\alpha_{0}+\alpha_{1} V D I_{i, t}+\alpha_{2} R O A_{i, t-1}+\alpha_{3} L E V_{i, t}+\alpha_{4} I F R S_{i, t}+\alpha_{5} S I Z E_{i, t}+\varepsilon_{i, t}$

Equation 6: $V D I_{i, t}=\alpha_{0}+\alpha_{1} D A_{i, t}+\alpha_{2} \operatorname{CON}_{i, t}+\alpha_{3} L I Q_{i, t}+\alpha_{4} I F R S_{i, t}+\alpha_{5} S I Z E_{i, t}+\varepsilon_{i, t}$

Note: standard error in parentheses.

$D A=$ discretionary accruals; CON = stock concentration; IFRS = dummy for the period of alignment with international

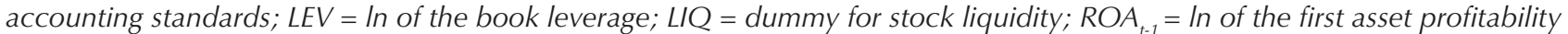
lag; $S I Z E=$ In of total assets; $V D I=$ voluntary disclosure index.

*,****: significant at the 10,5, and $1 \%$ levels, respectively.

Source: Prepared by the authors.

For the regression in which DA are the dependent variable, the only significant variable is LEV. This positive and significant relationship suggests that companies with high debt ratios tend to manage their earnings to show higher profit. Because it is a log-level function, all things being equal, a $10 \%$ increase in leverage has, on average, practically no effect on earnings management. This result shows that, although significant, the economic effect is very small. The other variables are not significant, nor do they show significant coefficients. These results contradict the theoretical assumption that these variables should be included in the model and, therefore, it is inferred that voluntary disclosure has no influence on variations in DA in the same time period. The analysis of the results for the regression in which voluntary disclosure (VDI) is the dependent variable shows that, with the exception of the ownership concentration variable $(\mathrm{CON})$, the other control variables are significant at the $1 \%$ or $5 \%$ level. The relationship of these variables is consistent with that which was expected.

Based on the results presented, a relationship between earnings management and voluntary disclosure in the 2005-2012 period is not found by the simultaneity test; even the regression analysis with panel data finds no association between them. If a unidirectional relationship was found in the current period, then it may be inferred that a dependent relationship existed between the variables of interest; that is, the decision about whether to make voluntary disclosure would depend on the prior choice of accounting policy and vice versa.

To allow the analysis of the influence of the independent variables on the dependent variables over time, dummy variables are included to control this dimension. In this study, the dummies are presented for 2006 to 2012, given that 2005 is taken as the reference year. Only the year 2008 was found to be significant in both models, it was demonstrated that there is a difference between the periods before and after 2008. This difference 
may have occurred because many current accounting regulations went into effect that year as Brazil aligned with international accounting standards; 2008 was also the year of the subprime lending crisis.

Although it is found that the DA and VDI variables do not appear to be associated in the current period, this study seeks to determine whether the level of voluntary disclosure at $t-1$ affects earnings management and whether earnings management at $t-1$ affects voluntary disclosure. New tests are conducted to test the relationship between voluntary disclosure in the prior period and earnings management and vice versa. Tests to identify the most appropriate panel data approach are again performed. The first two tests reject the null hypothesis that the pooled OLS model is appropriate, validating the alternative hypothesis that fixed or random effects models are appropriate. The result of the Hausman test indicates the random effects model is the most appropriate. Overall, the results do not differ from those found when the variables were analyzed for the current period alone (Table 4).

This finding shows that the relationship between earnings management and voluntary disclosure is not significant. Thus, there is no evidence that greater voluntary disclosure is reflected in a lesser propensity to manage earnings in the methodological context of this study. This finding contradicts the underlying theoretical assumptions and differs from the empirical results presented by Iatridis and Kadorinis (2009), Jo and Kim (2007), and Lobo and Zhou (2001) in addition to the study of Brazil by Murcia and Wuerges (2011). These studies conclude that voluntary disclosure is one of the factors inhibiting the practice of earnings management. It is important to note that the different methods and analyses used in each of these studies make it difficult to draw direct comparisons with the results found in this study.

\section{CONCLUSION}

The theoretical assumptions of this study were that, when managers decide the level of voluntary disclosure, they may be inclined to practice earnings management to shape market actors' perceptions to suit their plans, perhaps even acting in their own self-interest.

This study is based on the idea that voluntary disclosure contributes to the reduction or elimination of information asymmetry and that lower information asymmetry makes it more difficult to engage in earnings management. Therefore, companies with a higher index of voluntary disclosure tend not to practice earnings management. It was hypothesized that there is a negative relationship between these variables.

In the inferential analysis performed, it is found that voluntary disclosure and earnings management do not appear to be simultaneously determined. Based on the procedures employed in this study, it is not possible to infer a significant relationship between the measures used. Accordingly, the results are inconclusive with regard to the ability of the voluntary disclosure variable to explain whether companies are likely to manage earnings. The lack of a relationship between earnings management and voluntary disclosure suggests that disclosure decisions are not a determining factor in companies' involvement in earnings management in Brazil.

Although it may seem that this result contrasts with the assumption that voluntary disclosure reduces information asymmetry and hence limits the opportunistic practice of earnings management, this study does not consider under which conditions and at what time full disclosure is likely to occur. A market that values additional information may help raise the level of voluntary disclosure and improve the quality of information disclosed. Therefore, it is conceivable that the influence of voluntary disclosure on the extent of earnings management depends on the complex mix of companies' characteristics and factors related to the institutional environment.

One possible explanation for the results obtained is the perception that, in Brazil, many companies may have no intention of making high-quality voluntary disclosures because their controlling shareholders are in a comfortable position, taking advantage of private benefits that flow from their preferential access to information. This situation reduces the importance of the potential market demand for information, stratifies information asymmetry, and does not prevent opportunistic earnings management.

The companies listed on the BM\&FBOVESPA have gradually improved some aspects of corporate governance, but change has been very uneven. Brazilian companies are still marked by highly concentrated ownership and fragile corporate governance, with the concentration of control being made possible by the large number of nonvoting (preferred) shares issued and the use of pyramidal structures (Silveira, Leal, Barros, \& Carvalhal-da-Silva, 2009).

Due to the survival bias that guided the sampling process and measurement of the earnings management variable and the voluntary disclosure variable, it is noted 
that the reported results should be interpreted with caution. With regard to the estimation of DA, there are still doubts concerning the models' ability to measure earnings management, that is, to accurately distinguish between discretionary and non-discretionary components. The choice of model used reflects only the researcher's choice because the study was not intended to prove its effectiveness.

Research into aspects of companies' voluntary disclosure has difficulty obtaining an appropriate measure of disclosure. For various reasons, many researchers choose to develop their own measures. Although the metric's construction is grounded in previous studies and care is taken to identify the items whose disclosure has over time ceased to be voluntary, the process is not without subjectivity. Subjectivity can be present both in the selection of items and in the process by which they are coded.

It appears that several issues still need to be discussed in future studies. One should bear in mind that the literature on voluntary disclosure and earnings management is very dispersed, at times resembling a puzzle. This situation may be due to the differences in the conceptual understanding of each researcher, as well as their motivations. It is crucial to understand voluntary disclosure as a response to information asymmetry. As noted by Francis et al. (2008), the idea that voluntary disclosure is a determinant of earnings management ignores the fact that voluntary disclosure may also be based on poor information. This aspect makes it particularly difficult to identify the interaction between earnings management and voluntary disclosure.

Moreover, one of the great challenges of empirical research into earnings management and voluntary disclosure is the question of causality. Due to the hypothesis of the endogenous nature of causality, it is difficult to establish and identify the exact effect that one mechanism may have on the other. In this sense, the present study is only an attempt to investigate the relationship between them. The development or application of other methods can also make substantial contributions to this endeavor.

\section{REFERENCES}

Arya, A., Glover, J., \& Sunder, S. (1998). Earnings management and The Revelation Principle. Review Accounting Studies, 3, 7-34.

Beyer, A., Cohen, D. A., Lys, T. Z., \& Walther, B. R. (2010). The financial reporting environment: review of the recent literature. Journal of Accounting and Economics, 50, 296-343.

Botosan, C. A. (1997). Disclosure level and cost of equity capital. The Accounting Review, 72, 323-349.

Botosan, C. A: (2004). Discussion of a framework for the analysis of a firm risk communication. The International Journal of Accounting, 39, 289-295.

Botosan, C. A. (2006). Disclosure and the cost of capital: what do we know? Accounting and Business Research, 36, 31-40.

Burgstahler, D. C., Hail, L., \& Leuz, C. (2006). The importance of reporting incentives: earnings management in Europe private and public firms. The Accounting Review, 81(5); 883-1016.

Bushman, R. M., Engel, E., \& Smith, A. (2006). An analysis of the relation between the stewardship and valuation roles of earnings. Journal of Accounting Research, 44(1), 53-83.

Comissão de Valores Mobiliários/Normas Contábeis e Auditoria/ Superintendência de Relações com Empresas. 2007. OfícioCircular n. 480, de 14 de fevereiro de 2007. Orientações gerais sobre procedimentos a serem observados pelas companhias abertas. Retrieved from http://sistemas.cvm.gov.br/port/atos/ oficios/OFICIO-CIRCULAR-CVM-SNC-SEP-01_2007.asp.

Consoni, S., \& Colauto, R. D. (2016). Voluntary disclosure in the context of convergence with International Accounting Standards in Brazil. Review of Business Management, 18(62), 658-677.
Core, J. (2001). A review of the empirical disclosure literature: discussion. Journal of Accounting and Economics, 31, 441-456.

Dechow, P. M., \& Díchev, I. D. (2002). The quality of accruals and earnings: the role of accruals estimation errors. The Accounting Review, 77(4), 35-59.

Dechow, P. M., \& Skinner, D. (2000). Earnings management: reconciling the views of accounting academics, practitioners and regulators. Accounting Horizons, 14(2), 235-250.

Dechow, P. M., Sloan, R. G., \& Sweeney, A. P. (1995). Detecting earnings management. The Accounting Review, 70(2), 193-225.

Dechow, P., Ge, W., \& Schrand, C. (2010). Understanding earnings quality: a review of the proxies, their determinants and their consequences. Journal of Accounting and Economics, 50, 344401.

DeFond, M. (2010). Earnings quality research: advances, challenges and future research. Journal of Accounting and Economics, 50, 402-409.

Demsetz, H., \& Lehn, K. (1985). The structure of corporate ownership: cause and consequences. Journal of Political Economy, 93(6), 1155-1177.

Diamond, D., \& Verrecchia, R. E. (1991). Disclosure, liquidity and the cost of capital. The Journal of Finance, 46, 1325-1359.

Dye, R: A. (1985). Strategic accounting choice and effects of alternative financial reporting requirements. Journal of Accounting Research, 23, 544-574.

Dye, R. A. (1986). Proprietary and nonproprietary disclosures. Journal of Business, 59, 331-366.

Dye, R. A. (1988). Earnings management in an overlapping generation model. Journal of Accounting Research, 26, 195-235. 
Dye, R. A. (2001). An evaluation of "essays on disclosure" and the disclosure literature in accounting. Journal of Accounting and Economics, 32, 181-235.

Fields, T., Lys, T., \& Vincent, L. (2001). Empirical research on accounting choice. Journal of Accounting and Economics, 31(13), 255-307.

Francis, J., Nanda, D., \& Olsson, P. (2008). Voluntary disclosure, earnings quality e cost of capital. Journal of Accounting Research, 46(1), 53-99.

Glosten, L., \& Milgrom, P. (1985). Bid, ask, and transaction prices in a specialist market with heterogeneously informed traders. Journal of Financial Economics, 26, 71-100.

Grossman, S. J. (1981). The informational role of warranties and private disclosure about product quality. Journal of Law and Economics, 24, 461-484.

Guay, W. R., Kothari, S. P., \& Watts, R. (1996). A market-based evaluation of discretionary accrual models. Journal of Accounting Research, 34(Supplement 3), 83-105.

Healy, P. M. (1996). Discussion of a market based evaluation of discretionary accrual models. Journal of Accounting Research, 34(3), 107-115.

Healy, P. M., \& Wahlen, J. M. (1999). A review of earnings management literature and its implications for standard setting. Accounting Horizons, 13(4), 365-383.

Healy, P., \& Palepu, K. (2001). Information asymmetry, corporate disclosure and capital markets: a review of empirical disclosure literature. Journal of Accounting and Economics, 31, 405-440.

Iatridis, G., \& Kadorinis, G. (2009). Earnings management and firm financial motives: a financial investigation of UK listed firms. International Review of Financial Analysis, 18, 164-173.

Jo, H., \& Kim, Y. (2007). Disclosure frequency and earnings management. Journal of Financial Economics, 84, 561-590.

Kim, O., \& Verrecchia, R. E. (1994). Market liquidity and volume around earnings announcements. Journal of Accounting and Economics, 17, 41-68.

LaFond, R., \& Watts, R. L. (2008). The information role of conservatism. The Accounting Review, 83, 447-478.

Lambert, R. A. (2001). Contracting theory and accountings. Journal of Accounting and Economics, 32, 3-87.

Lambert, R. C., Leuz, C., \& Verrecchia, R. A. (2007). Accounting information, disclosure and de cost of capital. Journal of Accounting Research, 45, 385-420.

Levitt, A. (1998). The importance of high quality accounting standards. Accounting Horizons, 12, 79-82.

Lo, K. (2008). Earnings management and earnings quality. Journal of Accounting and Economics, 45(2-3), 350-357.

Lobo, G. J., \& Zhou, J. (2001). Disclosure quality and earnings management. Asia-Pacific Journal of Accounting and Economics, 8(1), 1-20.

Lopes, A. B., \& Alencar, R. C. (2010). Disclosure and cost of equity capital in emerging markets: the Brazilian case. The
International Journal of Accounting, 45, 443-464.

Lundholm, R. J. (2003). Historical accounting and the endogenous credibility of current disclosures. Journal of Accounting, Auditing and Finance, 18, 207-229.

Milgrom, P. (1981). Good news and bad news: representation theorems and applications. Bell Journal of Economics, 17, 1832.

Milgrom, P., \& Roberts, J. (1986). Relying on the information of interested parties. Rand Journal of Economics, 17, 18-32.

Mulford, C. W., \& Comiskey, E. E. (2002). The financial numbers games: detecting creative accounting practices. New York, NY: Wiley \& Sons.

Murcia, F. D., \& Wuerges, A. (2011). Escolhas contábeis no mercado brasilẹiro: divulgação voluntária de informações versus gerenciamento de resultados. Revista Universo Contábil $7(2), 28-44$

Myerson, R. (1979). Incentive compatibility and the bargaining problem. Econometrica, 47, 61-74.

Richardson, V. F. (2000). Information asymmetry and earnings management: some evidence. Review of Quantitative Finance and Accounting, 15, 325-347.

Schipper, K. (1989). Commentary on earnings management. Accounting Horizons, 3, 91-102.

Scott, W. R. (2012). Financial accounting theory (6th ed.). Toronto: Pearson.

Silveira, A. M., Leal, R. P. C., Barros, L. B. C., Carvalhal-daSilva, A. L. (2009). Evolution and determinants of firmlevel corporate governance quality in Brazil. Revista de Administração, 44(3), 173-189.

Subramanyam, K. R. (1996). The pricing of discretionary accruals. Journal of Accounting and Economics, 22, 249-281.

Thomas, J., \& Zhang, X. (2000). Identifying unexpected accruals: a comparison of current approaches. Journal of Accounting and Public Policy, 19(4-5), 347-376.

Trueman, B., \& Titman, S. (1988). An explanation for accounting income smoothing. Journal of Accounting Research, 26, $127-$ 139.

Verrecchia, R. E. (1983). Discretionary disclosure. Journal of Accounting and Economics, 5, 365-380.

Verrecchia, R. E. (2001). Essays on disclosure. Journal of Accounting and Economics, 32(1-3), 97-180.

Watts, R., \& Zimmerman, J. (1986). Positive accounting theory. Englewood Cliffs, NJ: Prentice Hall.

Welker, M. (1995). Disclosure policy, information asymmetry, and liquidity in equity markets. Contemporary Accounting Research, 11, 801-827.

Wooldridge, J. M. (2003). Introductory Econometrics. A modern approach. 2 Ed. Ohio: USA, Thomson South-Western.

Young, S. (1999). Systematic measurement error in the estimation of discretionary accruals: an evaluation of alternative modeling procedures. Journal of Business, Finance and Accounting, 26(7-8), 833-862.

\section{Correspondence address:}

\section{Silvia Consoni}

Universidade Federal do Paraná, Departamento de Ciências Contábeis

Avenida Prefeito Lothário Meissner, 632 - Campus III - CEP: 80210-070 Jardim Botânico - Curitiba - PR - Brasil

Email: silviaconsoni@ufpr.br 